\title{
PENGARUH PENGGUNAAN MEDIA GAMBAR TERHADAP KETERAMPILAN BERBICARA BAHASA INGGRIS
}

\author{
Doni Anggoro Ari Santoso ${ }^{1}$, Zumrotul Muniroh ${ }^{2}$, Nurul Akmaliah ${ }^{3}$ \\ don.okba@gmail.com
}

\author{
Program Studi Pendidikan Bahasa Inggris \\ Fakultas Bahasa dan Seni \\ Universitas Indraprasta PGRI
}

\begin{abstract}
Abstrak
Tujuan dari penelitian ini untuk mengetahui pengaruh penggunaan media gambar terhadap keterampilan berbicara mahasiswa Sekolah Tinggi Bahasa Asing Pertiwi, Cileungsi. Penelitian dengan menggunakan media gambar ini diharapkan dapat memberikan manfaat kepada para pengajar dan mahasiswa dalam melaksanakan kegiatan belajar mengajar khususnya dalam meningkatkan kemampuan berbicara bahasa Inggris. Metode yang digunakan dalam penelitian ini adalah metode eksperimen dengan menggunakan dua kelompok kelas. Satu kelas sebagai kelas eksperimen, dimana peneliti menyampaikan materi pembelajaran dengan menggunakan media gambar. Sedangkan, satu kelas lainnya sebagai kelas kontrol, dimana materi pembelajaran disampaikan dengan metode ceramah. Berdasarkan hasil analisis data, dapat disimpulkan bahwa nilai rata-rata keterampilan berbicara bahasa Inggris kelas kontrol adalah sebesar 64,7. Nilai median sebesar 61,5. Nilai modus sebesar 57,5. Nilai varians sebesar 258,6256. Dan, nilai simpangan baku sebesar 16,082. Sedangkan, nilai rata-rata keterampilan berbicara bahasa Inggris kelas eksperimen adalah sebesar 70,5. Nilai median sebesar 71,21. Nilai modus sebesar 85,056. Nilai varians sebesar 229,128. Dan, nilai simpangan baku sebesar 15,14. Selanjutnya, diperoleh Persamaan $\mathrm{S}_{\text {gab }}$ sebesar 15,62. Dan, hasil nilai $t_{\text {hitung }}$ sebesar 1,69 dan $t_{\text {tabel }}$ sebesar 1,667. Dengan demikian, diketahui bahwat $_{\text {hitung }}>\mathrm{t}_{\mathrm{tabel}} ; 1,69>1,667$ yang berarti signifikan. Maka, dapat disimpulkan bahwa terdapat pengaruh yang positif dan signifikan penggunaan media gambar terhadap keterampilan berbicara bahasa Inggris pada mahasiswa STBA Pertiwi, Cileungsi.
\end{abstract}

Kata Kunci: Penggunaan Media Gambar, Keterampilan Berbicara

\begin{abstract}
The purpose of this research is to find out the effect of the using of flash cards towards student's speaking ability in STBA Pertiwi, Cileungsi. The researchers hope that this research can give advantages to all of lecturers and students in doing the learning process, especially in English speaking ability. The method used in this research is experiment method using two groups of classes. One class as experiment class, where the researchers are giving the materials using flash cards. While the other class is control class, where the materials are given with lecturing method. Based on the result of the data analysis, it can be concluded that the average score for English speaking ability in control class is 64,7. The median is 61.5. The modus is 57,5. The variance is 258, 6256. And the standard deviation is 16,082. In the other hand, the average score for English speaking ability in experiment class is 70,5. The median is 71,21. The modus is 85,056. The variance is 229, 128. And the standard deviation is 15,14. It is also obtained that the equation of Total Variance is 15,62. And the $T_{\text {Observed }}$ is 1,69 and the $T_{\text {table }}$ is 1,667. So that $T_{\text {observed }}>T_{\text {table }} ; 1,69>1,667$ that is significant. It can be concluded that there is positive and significant effect of using of flash cards towards student's speaking ability in STBA Pertiwi, Cileungsi.
\end{abstract}

Key words: the use of flash cards, speaking ability

\section{PENDAHULUAN}

Pendidikan merupakan faktor utama dalam membentuk kualitas sumber daya manusia dalam suatu Negara. Pendidikan bersifat dinamis sehingga selalu menuntut suatu perbaikan dalam pelaksanaannya secara terus menerus. Peran pendidikan sangatlah penting untuk menciptakan kehidupan yang cerdas, dinamis, dan demokratis. Oleh karena itu, pembaruan pendidikan 
harus terus dilakukan guna meningatkan kualitas pendidikan nasional. Berbagai upaya telah dilakukan, misalnya pembaruan kurikulum, peningkatan kualitas guru, penyediaan kepustakaan, penyediaan laboratorium, penataan manajemen pendidikan, dan penerapan produk teknologi.

Pembelajaran yang diharapkan dari tujuan pendidikan nasional adalah pembelajaran yang aktif (active learning) yang dimaksudkan untuk menjaga perhatian siswa agar tetap tertuju pada proses pembelajaran secara menyeluruh. Pembelajaran yang aktif demikian, dapat kita rancang dengan adanya penggunaan berbagai media, model, dan metode pembelajaran yang menarik, sehingga peserta didik tidak cepat bosan, selalu fokus, dan menyenangkan tanpa kehilangan esensi belajar yang sedang berlangsung.

Kesiapan pendidik dalam menggunakan media, model, dan metode pembelajaran adalah suatu keharusan dalam mencapai tujuan pendidikan. Pendidik juga dituntut menggunakan beragam media, model, dan metode pembelajaran dalam melaksanakan proses pembelajaran. Kreativitas pendidik juga diharapkan muncul guna menciptakan pembelajaran yang menarik dan menyenangkan.

Dalam penelitian ini, peneliti menggunakan media dalam proses pembelajaran. Media merupakan alat atau perantara yang digunakan untuk

182 | Jurnal Kredo Vol. 2 No. 2 April 2019 menyampaikan dan menyajikan suatu pesan atau informasi. Penggunaan suatu media dapat efektif dalam proses pembelajaran karena dapat menarik fokus mahasiswa saat proses pelajaran berlangsung. Pengelompokkan media dibagi menjadi tiga macam, yakni media audio (mengandalkan indera pendengaran), media visual (mengandalkan indera penglihatan), dan media audio visual (menampilkan suara dan gambar).

Salah satu media pembelajaran yang digunakan oleh peneliti yang lebih efektif, yakni menggunakan media visual berupa gambar. Penggunaan media gambar merupakan media pembelajaran yang efektif karena menarik perhatian mahasiswa. Mahasiswa dapat langsung tertarik dengan sesuatu yang dilihat secara langsung melalui indera penglihatan yang merangsang kinerja otak siswa untuk mengembangkan dan menyampaikan ide, gagasan dan pikiran dari apa yang dilihatnya.

Dengan penggunaan media tersebut, peneliti percaya bahwa mahasiswa lebih mudah mempelajari dan menguasai keterampilan berbicara. Berbicara adalah kemampuan untuk mengekspresikan perasaan, menyatakan pendapat, dan menyampaikan gagasan. Peneliti menggunakan media gambar agar efektif dalam mempelajari keterampilan berbicara, karena gambar merupakan media yang dapat 
merangsang kinerja otak siswa dalam menyampaikan apa yang dilihatnya.

Berdasarkan pemikiran tersebut, peneliti tertarik untuk melaksanakan penelitian dengan judul, "Pengaruh Penggunaan Media Gambar terhadap Keterampilan Berbicara." Penelitian ini dilaksanakan di Sekolah Tinggi Bahasa Asing Pertiwi yang berlokasi di Cileungsi, Jawa Barat.

\section{TINJAUAN PUSTAKA}

\section{Pengertian Hakikat Bahasa Inggris}

Bahasa Inggris merupakan media komunikasi utama bagi masyarakat di Negara Inggris, Amerika Serikat, New Zealand, Australia, Kanada, Afrika Selatan, dan dibanyak Negara lainnya. Bahasa Inggris merupakan bahasa yang digunakan untuk berinteraksi dengan orang lain di seluruh dunia.

Hornby (2006:486) menyatakan bahwa "English is the language originally of England, now spoken in many other countries and used as language of international communication throughout the world." Saat ini setiap individu merasa perlu mempelajari bahasa Inggris, dengan bahasa Inggris seseorang dapat berkomunikasi dengan orang asing yang ditemui di dalam negeri ataupun ketika berada di luar negeri.

McKay (2009:1) menyatakan bahwa, "English is an international language and that teaching it as such entails unique language teaching goals and approaches." bahasa Inggris merupakan bahasa internasional dan mengajarnya memerlukan tujuan pengajaran bahasa yang unik dan pendekatan untuk mencapainya. McKay (2009:12) juga mengatakan bahwa, "English is used by individuals to communicate with people of other countries." Bahasa Inggris digunakan oleh individu untuk berkomunikasi dengan orang-orang dari Negara lain, sehingga penting setiap individu memahami bahasa Inggris untuk dapat berkomunikasi dengan orang lain di seluruh dunia.

Bahasa Inggris merupakan bahasa yang sangat kompleks, karena bahasa Inggris terpaku dalam penekanan pentingnya struktur atau aturan bahasa (Grammar) dan akurasi penggunaannya dalam bahasa percakapan maupun tulisan. Kita harus mengetahui tata bahasa dari bahasa Inggris, kosakata, dan cara baca atau pengucapan bahasa Inggris tersebut. Dalam mempelajari bahasa Inggris kita dituntut untuk mampu menguasai semua unsurunsur yang ada.

Bahasa Inggris adalah bahasa internasional yang memiliki peranan penting sebagai alat komunikasi dengan bangsa lain, sehingga sebaiknya kita menguasai bahasa tersebut. Dengan kita mampu menguasai bahasa Inggris maka kita akan bisa berkomunikasi dan berinteraksi dengan orang-orang di 
Negara lain, karena bahasa Inggris sebagai bahasa internasional.

Dalam mempelajari bahasa Inggris sangat penting untuk mengetahui sejarah bahasa Inggris. Sejarah bahasa Inggris disebut "English Literature”. Bahasa Inggris mempunyai berbagai bentuk yang sesuai dengan konteks dan keadaan.

Menurut Celce (2001:8) dalam bukunya "Teaching English as second for Foreign Language". Menyatakan bahwa "English often serves as a language of communication between speakers of different primary language." Jadi bahasa Inggris adalah bahasa internasional yang digunakan dalam kegiatan berkomunikasi supaya siswa, mahasiswa ataupun masyarakat tidak ketinggalan zaman, mereka harus mempelajarinya. Oleh karena itu, bahasa Inggris diajarkan mulai dari sekolah dasar sampai Perguruan Tinggi.

\section{Pengertian \\ Berbicara}

Keterampilan

Berbicara merupakan salah satu keterampilan berbahasa dalam bentuk lisan. Berbicara adalah bentuk bahasa yang menggunakan artikulasi atau kata-kata yang digunakan untuk menyampaikan pendapat. Tujuan berbicara adalah untuk berkomunikasi atau menuangkan ide dan gagasanya dengan baik.

Keterampilan berbahasa yang harus dimiliki oleh seluruh peserta didik di sekolah meliputi empat

184 | Jurnal Kredo Vol. 2 No. 2 April 2019 aspek dasar, yaitu keterampilan mendengarkan atau menyimak (listening skill), berbicara (speaking skill), membaca (reading skill), menulis (writing skill) (Tarigan, 2015:1). Keterampilan berasal dari kata dasar terampil yang berarti cakap, mampu, dan cekatan dalam menyelesaikan tugas. Menerampilkan berarti membuat menjadi terampil atau memberikan keterampilan. Keterampilan secara bahasa adalah kecakapan untuk menyelesaikan tugas dan kecakapan dalam pemakaian bahasa baik secara lisan maupun tulis, sedangkan keterampilan secara tematis adalah kesanggupan pemakai bahasa untuk menanggapi secara benar stimulus lisan atau tulisan, menggunakan pola gramatikal dan kosakata secara tepat, dan menerjemahkan dari satu bahasa ke bahasa lain.

Seseorang dikatakan mempunyai keterampilan apabila orang tersebut mempunyai kesanggupan untuk berbuat dan melakukan tindakan dengan mudah dan tepat setelah melalui belajar. Agar terampil seseorang harus belajar. Hal ini menunjukkan bahwa keterampilan seseorang tidak sertamerta bisa terampil dengan sendirinya tetapi harus dengan pembelajaran terlebih dahulu. Seseorang semakin termotivasi belajar maka keterampilannya semakin terarah.

Menurut Tarigan (2015:14) menyatakan bahwa keterampilan berbicara adalah keterampilan 
mengucapkan bunyi-bunyi artikulasi atau mengucapkan kata-kata untuk mengekspresikan, menyatakan, menyampaikan pikiran, gagasan, perasaan terhadap pendengar. Pendengar menerima informasi melaui rangkaian nada, tekanan, dan penempatan persendian.

Tujuan utama berbicara adalah untuk berkomunikasi. Agar dapat menyampaikan pikiran secara efektif, maka si pembicara harus memahami makna segala sesuatu yang ingin dikomunikasikan. Ia harus mampu mengevaluasi efek komunikasinya terhadap para pendengarnya, dan harus mengetahui prinsip-prinsip yang mendasari segala situasi pembicaraan, baik secara umum maupun perorangan. Dengan demikian berbicara merupakan bagian dari kemampuan berbahasa yang aktif-produktif.

Sebagai bagian dari kemampuan berbahasa yang aktifproduktif, kemampuan berbicara menuntut penguasaan terhadap beberapa aspek dan kaidah penggunaan bahasa. Secara kebahasaan pesan lisan disampaikan dengan berbicara menggunakan katakata yang dipilih sesuai dengan maksud yang perlu diungkapkan. Kata-kata dirangkai dalam susunan tertentu menurut kaidah tata bahasa, dan dilafalkan sesuai dengan kaidah pelafalan yang sesuai pula, supaya pesan yang disampaikan dapat diterima dan dimengerti seperti yang dimaksudkan oleh pembicara.
Berdasarkan pendapat tersebut, peneliti dapat menyimpulkan bahwa keterampilan berbicara adalah keterampilan berkomunikasi untuk mengungkapkan gagasan kepada pihak lain secara lisan.

\section{Aspek dalam Berbicara}

Brown (2010:172-173) menjelaskan setidaknya ada empat aspek dalam berbicara yang harus diketahui oleh peserta didik agar dapat berbicara bahasa Inggris sebagai berikut.

1) Vocabulary

First speaking vocabulary inadequate to express anything but the most elementary needs. Second has speaking vocabulary sufficient to express himself simply with some circumlocution. Third able to speak the language with sufficient vocabulary to practicipate effectively in most formal and informal conversation on practical, social, and professional topics.

2) Fluency

First able to use the language fluently an all levels normally pertinent to professional needs. Can practicipate in any conversation whitin the range on this experience with a high degree of fluency. Second (no specific fluency description. Refer to other four language areas for implied level of fluency). Third can handle with confidence but not with facility most social situations, including, introduction and casual 
conversations about current events, as well asa work, family, and autoboigraphial information.

\section{3) Pronunciation}

First equivalent to and fully accepted by educative native speaker. Second errors in pronunciation are frequent but can be understood by a native speaker used to dealing with foreigners attempting to speak his language. Third accent is intelligible though often quite faulty.

\section{4) Comprehension}

First can understand any conversation whitin the range of his experience. Second can get the gist of most conversation of nontechnical subject (i.e., topics that require no specialized knowledge). Third comprehension is quite complete at a normal rate of speech.

Dapat disimpulkan dari penjabaran aspek berbicara tersebut bahwa siswa dalam berbicara harus memperhatikan kosakata yang akan digunakan, pemahaman tetang maksud yang dibicarakan, dalam pengucapan pun harus baik dan dapat dimengerti, serta kelancaran dalam berbicara. Keempat aspek tersebut dapat membantu siswa dalam meningkatkan keterampilan berbicara bahasa Inggris.

Selain terdapat aspek dalam berbicara, berbicara tentu memiliki tujuan yang ingin disampaikan kepada lawan bicaranya. Agar tujuan itu dapat disampaikan dengan baik dan efektif, maka pembicara harus memahami hal yang ingin disampaikan dan menguasai aspek keterampilan berbicara. Dalam hal itu pendengar dapat memaknai informasi atau pesan yang disampaikan oleh pembicara.

Tarigan

(2015:16) mengungkapkan bahwa kegiatan berbicara memiliki tujuan utama untuk berkomunikasi. Untuk menyampaikan pikiran secara efektif, berbicara harus memahami makna sesuatu hal yang akan dikomunikasikan. Dia juga harus mengevaluasi efek komunikasinya terhadap para pendengar dan harus mengetahui prinsip-prinsip yang mendasari segala situasi pembicaraan, baik secara umum maupun secara perorangan.

\section{Pengertian Media Gambar}

Kata "media" berasal dari bahasa Latin dan bentuk jamak dari kata "medius", yang secara harfiah berarti tengah, perantara atau pengantar. Dalam bahasa Arab, media adalah perantara atau pengantar pesan dari pengirim kepada penerima pesan. Dengan demikian, maka media merupakan wahana penyalur informasi belajar atau penyalur pesan. Media merupakan alat yang digunakan sebagai perantara untuk menyampaikan pesan dan dapat merangsang pikiran, perasaan dan kemajuan siswa sehingga dapat mendorong terjadinya proses belajar mengajar.

Menurut Sadiman (2009:7) mengemukakan sebagai berikut.

$\begin{array}{lr}\text { "Media adalah segala } \\ \text { sesuatu yang dapat } \\ \text { dipergunakan } & \text { untuk } \\ \text { menyalurkan pesan dari } \\ \text { pengirim ke penerima pesan }\end{array}$


sehingga dapat merangsang pikiran, perasaan, perhatian dan minat siswa sedemikian rupa sehingga proses belajar terjadi”.

Berdasarkan pendapat tersebut apapun yang menjadi alat atau bahan dalam menyampaikan pesan atau informasi sehingga pesan atau informasi dapat dimengerti dan dipahami dengan baik oleh penerima pesan disebut dengan media.

Guru yang efektif dalam menggunakan media dapat meningkatkan minat siswa dalam proses belajar mengajar dan siswa lebih cepat dan mudah dalam memahami dan mengerti materi yang disampaikan oleh guru. Akan tetapi, perlu diperhatikan, penggunaan media tidak efektif apabila penggunaannya tidak sejalan dengan isi dan tujuan yang disampaikan. Oleh sebab itu, tujuan pengajaran harus dijadikan pangkal acuan untuk menggunakan media. Apabila tujuan pengajaran diabaikan, maka media bukan lagi sebagai alat bantu pengajaran, tetapi sebagai penghambat dalam pencapaian tujuan secara efektif dan efisien.

Media pembelajaran adalah suatu hal yang sangat penting penggunaannya dalam kegiatan belajar mengajar. Media pembelajaran secara bahasa dibagi menjadi dua suku kata, yakni media yang berarti alat dan pembelajaran yang berarti proses penyampaian informasi atau pengetahuan dari tenaga pendidik kepada peserta didik. Berdasarkan penjelasan tersebut, maka dapat disimpulkan bahwa media pembelajaran adalah alat atau bahan bantu yang di dalamnya terkandung informasi atau pengetahuan yang digunakan dalam proses belajar mengajar. Tujuan penggunaan media pembelajaran untuk memperlancar jalannya komunikasi dalam proses pembelajaran.

Menurut Schram dalam Rudi Susilana (2007:6) menyatakan bahwa "Media pembelajaran adalah teknologi pembawa pesan yang dapat dimanfaatkan dalam pembelajaran." Ini berarti media pembelajaran adalah alat atau bahan yang menjadi pendukung dalam menyampaikan pesan selama proses belajar mengajar berlangsung.

Menurut Richard \& Renandiya (2002: 2) menyatakan bahwa "Instructional media can reduce the burden of teachers in delivering teaching materials, so that they can concentrate on teaching in the classroom." Teori tersebut menunjuk makna bahwa media pembelajaran dapat mengurangi beban bagi tenaga pendidik atau guru dalam menyampaikan informasi atau pengetahuan, sehingga tenaga pendidik dapat dengan mudah menarik perhatian peserta didik sehingga peserta didik memiliki konsentrasi penuh dalam menerima informasi atau pengetahuan selama didalam kelas.

Fungsi pokok media pembelajaran, yakni sebagai alat bantu untuk mewujudkan situasi belajar mengajar yang efektif, mempercepat proses belajar mengajar, membantu siswa dalam 
menangkap pengertian dan pembelajaran yang diberikan oleh guru dan dapat meningkatkan dan mempertinggi mutu belajar.

Ada beberapa jenis media pembelajaran yang bisa digunakan dalam proses pembelajaran.

a) Media grafis atau dua dimensi adalah media yang mempunyai ukuran panjang dan lebar. Seperti gambar, foto, grafik, bagan atau diagram, poster, dan kartun.

b) Media tiga dimensi, yaitu media dalam bentuk model susun, model kerja, mock up, diorama.

c) Media proyeksi seperti slide, film strips, film, penggunaan OverHead Projection

d) Penggunaan lingkungan sebagai media pembelajaran

Dengan keberagaman jenis media dan fungsi media tersebut, maka kita sebagai seorang guru, harus bisa memilih media pembelajaran yang tepat sehingga media tersebut dapat digunakan dengan efektif dan efisien. Dalam memilih media pembelajaran, ada beberapa hal yang perlu diperhatikan oleh guru, yakni media harus sesuai dengan tujuan yang ingin dicapai, kondisi dan keterbatasan yang ada dengan mengingat kemampuan dan karakteristik media, ketepatgunaan media, kondisi siswa, kesediaan barang, biaya dan waktu yang diperlukan untuk mendapatkannya.

Pemilihan media pembelajaran bersumber dari konsep bahwa media merupakan bagian dari sistem instruksional secara keseluruhan. Ada beberapa kriteria yang perlu

188 | Jurnal Kredo Vol. 2 No. 2 April 2019 diperhatikan dalam memilih media pembelajaran sebagai berikut.

a) Ketepatannya dengan tujuan pengajaran. Maksudnya bahwa media pengajaran dipilih atas dasar tujuan-tujuan instruksional yang berisikan unsur-unsur pemahaman, aplikasi, analisis, sintesis, lebih mungkin digunakannya media pengajaran.

b) Dukungan terhadap isi bahan pelajaran. Bahan pelajaran yang sifatnya fakta, prinsip, konsep dan generalisasi sangat memerlukan bantuan media agar lebih mudah dipahami oleh peserta didik.

c) Kemudahan memperoleh media. Media yang diperlukan mudah diperoleh setidak-tidaknya mudah dibuat oleh tenaga pendidik pada waktu mengajar.

d) Keterampilan guru dalam menggunakan media. Apapun jenis media yang diperlukan syarat utamanya guru dapat menggunakannya dalam proses belajar mengajar. Nilai dan manfaat yang diharapkan adalah pada dampak dari penggunaannya oleh guru pada saat terjadinya interaksi belajar siswa dengan lingkungannya.

e) Tersedia waktu untuk menggunakannya, sehingga media dapat bermanfaat bagi siswa selama pengajaran berlangsung.

f) Sesuai dengan taraf berpikir peserta didik. Memilih media untuk pendidikan dan pengajaran harus sesuai dengan taraf berpikir siswa, sehingga makna yang terkandung di dalamnya dapat dipahami oleh siswa.

Djamarah \&Zain (2010:124) menyatakan bahwa media yang 
dikenal dewasa ini tidak hanya terdiri dari dua jenis, tetapi sudah lebih dari itu. Pengelompokan media dapat dilihat dari jenisnya, daya liputnya, dan dari bahan serta cara pembuatannya. Bila dilihat dari jenisnya media dibagi menjadi berikut ini.

\section{1) Media Audititif}

Media Audititif. Media yang hanya mengandalkan suara saja, seperti radio, cassette recorder, dan piringan hitam. Media ini tidak cocok untuk orang yang memiliki kelainan pada pendengaran.

2) Media Visual

Media yang hanya mengandalkan indera penglihatan saja. Media ini ada yang hanya menampilkan gambar diam seperti film strip, slides, foto, gambar atau lukisan, dan cetakan. Ada pula media visual yang menampilkan gambar atau simbol yang bergerak seperti film bisu, dan film kartun.

3) Media Audiovisual

Media audiovisual adalah media yang mempunyai unsur suara dan unsur gambar. Jenis media ini mempunyai kemampuan yang lebih baik, karena meliputi kedua jenis media yang pertama dan yang kedua.

Penggunaan media gambar merupakan salah satu metode presentasi alternatif yang mampu memberi informasi kepada peserta didik secara cepat dengan membayangi apa yang mereka bayangkan. Media gambar adalah media yang mengandung makna yang lebih baik dibandingkan dengan tulisan, karena di dalam gambar terdapat bahasa yang umum yang mudah dipahami dan dimengerti.

Kelebihan media gambar menurut Sadiman, dkk (2009: 29) sebagai berikut.

1) Sifatnya konkret. Gambar lebih realistis menunjukkan pokok masalah dibandingkan dengan media verbal semata.

2) Gambar dapat mengatasi batasan ruang dan waktu.

3) Media gambar dapat mengatasi keterbatasan pengamatan kita.

4) Gambar dapat memperjelas suatu masalah, dalam bidang apa saja dan untuk tingkat usia berapa saja, sehingga dapat mencegah atau membetulkan kesalahan.

5) Gambar harganya murah dan mudah didapat serta digunakan, tanpa memerlukan peralatan khusus.

Media gambar hanya mengandalkan indera penglihatan dan ukurannya terbatas untuk kelompok besar. Oleh karena itu, gambar yang baik untuk digunakan sebagai media pembelajaran harus memenuhi syarat-syarat sebagai berikut.

1) Autentik adalah gambar harus menunjukkan situasi yang sebenarnya seperti yang dilihat orang.

2) Sederhana adalah komposisi gambar harus jelas menunjukkan poin pokok dalam gambar. 
3) Ukuran relatif adalah mampu memperbesar dan memperkecil benda atau objek yang sebenarnya

4) Gambar sebaiknya mengandung gerak atau perbuatan

5) Gambar hendaklah bagus dari segi seni dan sesuai dengan tujuan pembelajaran.

\section{METODE PENELITIAN}

Metode yang digunakan dalam penelitian ini adalah metode eksperimen dengan menggunakan dua kelompok kelas.

Dalam pelaksanaan penelitian eksperimen, kelompok eksperimen dan kelompok kontrol sebaiknya diatur secara intensif sehingga kedua variabel mempunyai karakteristik yang sama atau mendekati sama. Yang membedakan dari kedua kelompok ialah bahwa kelompok eksperimen diberikan perlakuan tertentu, sedangkan kelompok kontrol diberikan perlakuan seperti keadaan biasanya. Verifikasi hasilnya diperoleh dengan membandingkan antara kelas eksperimen dengan kelas kontrol (non experiment).

\section{Rancangan Penelitian}

Berdasarkan pada metode yang digunakan dalam penelitian, yakni metode eksperimen, desain eksperimen dalam penelitian ini adalah posttest-Only Control Design. Dalam desain ini menggunakan pemilihan subjek secara acak dan melibatkan dua kelompok subjek, yakni kelompok eksperimen atau kelompok yang diberikan perlakuan dan kelompok kontrol atau kelompok yang tidak diberikan perlakuan (hanya menggunakan model ceramah ). Pada desain ini, tiap-tiap kelompok tidak diberikan tes awal atau pretest untuk mengetahui kondisi awalnya namun diberikan tes akhir atau post test untuk mengetahui gejala yang terjadi setelah diberikan perlakuan. Pada kelompok kontrol tidak diberikan perlakuan atau treatment tetapi diberikan tes yang sama dengan kelompok eksperimen kemudian hasil tes akhir atau post test keduanya dibandingkan. Berdasarkan perbandingan tersebut, maka dapat diketahui apakah ada perubahan dan peningkatan kemampuan menulis bahasa Inggris setelah menggunakan media gambar atau tidak. Oleh sebab itu, desain penelitian yang digunakan sebagai berikut.

\section{Gambar 1. Desain Penelitian}

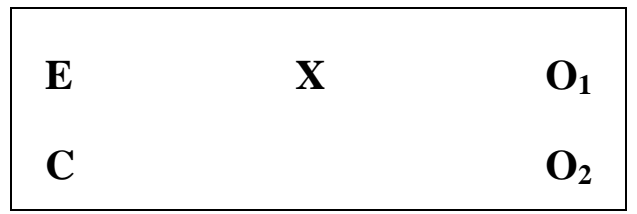

E : Kelompok eksperimen

C : Kelompok kontrol

$\mathrm{X}$ : Perlakuan atau treatment dengan menggunakan media gambar

$\mathrm{O}_{1}$ : Hasil tes (post test) setelah diberikan perlakuan pada kelompok eksperimen

$\mathrm{O}_{2}$ : Hasil tes (post test) tanpa diberikan perlakuan pada kelompok kontrol 


\section{Proses Pengumpulan Data}

\section{Variabel Penelitian}

Variabel adalah objek dari penelitian atau apa yang menjadi pusat penelitian dari suatu penelitian. Ada dua macam variabel dalam penelitian sebagai berikut.

a. Media gambar sebagai variabel bebas (X) berfungsi sebagai pihak yang mempengaruhi.

b. Keterampilan berbicara bahasa Inggris sebagai variabel terikat (Y) berfungsi sebagai pihak yang dipengaruhi.

\section{Sumber Data}

Peneliti mendapatkan sumber data dari hasil post test berupa tes lisan yang diberikan kepada semua mahasiswa STBA Pertiwi yang menjadi sampel kelas eksperimen dan kelas kontrol. Hasil dari tes tersebut dikumpulkan kemudian diolah dan dibuat laporan.

\section{Teknik Pengumpulan dan Analisis Data}

\section{Teknik Pengumpulan Data}

Untuk memperoleh data yang relevan dan sesuai dengan kepentingan penelitian ini, diperlukan sebuah teknik pengumpulan tes yang sesuai dengan rumusan dan tujuan penelitian. Dalam penelitian ini, peneliti memilih teknik pengumpulan data melalui tes. Tes adalah sejumlah pertanyaan atau latihan serta alat lain yang digunakan untuk mengukur keterampilan, pengetahuan intelegensi, kemampuan atau bakat yang dimiliki oleh individu atau kelompok. Tes digunakan untuk mengetahui keterampilan berbicara bahasa Inggris siswa melalui penggunaan media gambar didalam proses belajar mengajar.

Tes yang diujikan pada penelitian ini, yakni post test. Post test adalah bentuk pertanyaan yang diberikan setelah pelajaran atau materi disampaikan. Dengan kata lain post test adalah evaluasi yang dilakukan satu kali, yakni pada akhir setelah materi ajar pada hari itu diberikan oleh guru. Post test ini dengan maksud untuk mengetahui apakah mahasiswa sudah paham dan mengerti mengenai materi ajar tersebut atau belum. Post test ini diujikan pada kelompok kontrol yang tidak diberikan perlakuan dan kelompok eksperimen yang diberikan perlakuan. Kemudian hasil dari kedua kelompok tersebut dibandingkan.

\section{Teknik Analisis Data}

Teknik analisis data yang digunakan dalam penelitian ini meliputi uji deskriptif, uji persyaratan data yang didalamnya terdapat uji normalitas dan uji homogenitas, serta uji hipotesis.

\section{HASIL DAN PEMBAHASAN}

\section{Deskripsi Data}

Data diperoleh dari dua kelompok kelas yang masing-masing 
sejumlah 40 siswa kemudian dianalisis.

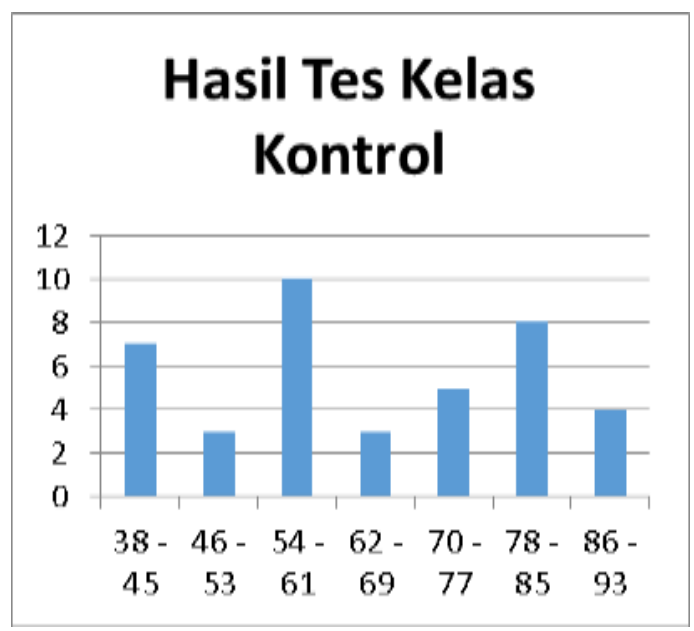

Gambar 2. Hasil Tes Kelas Kontrol

Berdasarkan hasil perhitungan, diperoleh hasil nilai rata-rata keterampilan berbicara bahasa Inggris kelas kontrol adalah sebesar 64,7. Nilai median sebesar 61,5. Nilai modus sebesar 57,5. Nilai varians sebesar 258,6256. Nilai simpangan baku sebesar 16,082.

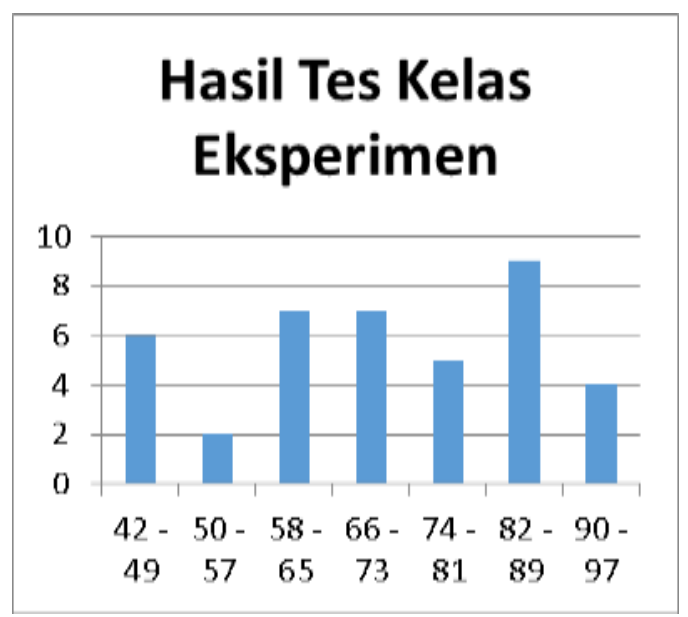

Gambar 2. Hasil Tes Kelas Eksperimen

Diperoleh hasil nilai rata-rata keterampilan berbicara bahasa Inggris kelas eksperimen adalah sebesar 70,5. Nilai median sebesar

192 | Jurnal Kredo Vol. 2 No. 2 April 2019
71,21. Nilai modus sebesar 85,056. Nilai varians sebesar 229,128. Dan, nilai simpangan baku sebesar 15,14.

\section{Uji Persyaratan Data}

\section{Uji Normalitas}

Dari hasil uji normalitas, diperoleh hasil sebagai berikut:

\begin{tabular}{llll}
\hline Data & $\begin{array}{l}\text { Lo } \\
\text { Hitung }\end{array}$ & $\begin{array}{l}\text { Lo } \\
\text { Tabel }\end{array}$ & Ket \\
\hline Kontrol & $\mathbf{0 , 0 9}$ & $\mathbf{0 , 1 4 0}$ & Normal \\
Eksperimen & $\mathbf{0 , 0 9 1}$ & $\mathbf{0 , 1 4 0}$ & Normal \\
\hline \multicolumn{2}{c}{ Tabel } & 1. Uji & Normalitas \\
& & &
\end{tabular}

Dari tabel di atas dapat dilihat bahwa nilai Lo hitung kelas kontrol sebesar 0,09 dan Lo hitung kelas eksperimen 0,091. Kedua nilai tersebut lebih kecil dari nilai Lo tabel sebesar 0,140. Oleh sebab itu, dapat disimpulkan bahwa kedua kelompok data berdistribusi normal.

\section{Uji Homogenitas}

Selanjutnya dari hasil uji homogenitas, dapat disimpulkan bahwa kedua kelompok data bersifat homogen karena nilai $F_{\text {hitung }}$ sebesar 1,13 lebih kecil dari nilai $F_{\text {tabel }}$ sebesar 1,69.

\section{Uji Hipotesis}

Selanjutnya, dalam pengujian hipotesis, diperoleh Persamaan $\mathrm{S}_{\mathrm{gab}}$ sebesar 15,62. Berikutnya, penulis mendapatkan hasil nilai $t_{\text {hitung }}$ sebesar 1,69 dan $t_{\text {tabel }}$ sebesar 1,667. Dengan demikian, diketahui bahwa $t_{\text {hitung }}>$ $\mathrm{t}_{\text {tabel }} ; \quad 1,69>1,667$ yang berarti signifikan.

Maka, dapat disimpulkan bahwa terdapat pengaruh yang positif dan signifikan penggunaan media gambar terhadap keterampilan berbicara 
bahasa Inggris pada mahasiswa STBA Pertiwi, Cileungsi.

Hasil dari penelitian ini juga dapat dilihat dari tabel sebagai berikut:

\begin{tabular}{lll}
\hline Nilai & Kelas & Kelas \\
& Kontrol & Eksperimen \\
\hline Mean & $\mathbf{6 4 , 7}$ & $\mathbf{7 0 , 5}$ \\
Median & $\mathbf{6 1 , 5}$ & $\mathbf{7 1 , 2}$ \\
Modus & $\mathbf{5 7 , 5}$ & $\mathbf{8 5 , 0 6}$ \\
Standar Devasi & $\mathbf{1 6 , 0 9}$ & $\mathbf{1 5 , 1 4}$ \\
Varians & $\mathbf{2 5 8 , 6 3}$ & $\mathbf{2 2 9 , 1 3}$ \\
\hline
\end{tabular}

Tabel 2. Tabel Perbandingan Kelas

\section{PENUTUP}

\section{Simpulan}

Setelah memperhatikan hasil penelitian di atas, maka dapat disimpulkan sebagai berikut.

Nilai rata-rata keterampilan berbicara bahasa Inggris kelas kontrol adalah sebesar 64,7. Nilai median sebesar 61,5. Nilai modus sebesar 57,5. Nilai varians sebesar 258,6256 . Dan, nilai simpangan baku sebesar 16,082 .

Sedangkan, nilai rata-rata keterampilan berbicara bahasa Inggris kelas eksperimen adalah sebesar 70,5. Nilai median sebesar 71,21 . Nilai modus sebesar 85,056. Nilai varians sebesar 229,128. Dan, nilai simpangan baku sebesar 15,14.

Kemudian, berdasarkan hasil uji normalitas, diperoleh hasil Lo hitung kelas kontrol sebesar 0,09 dan Lo hitung kelas eksperimen 0,091. Kedua nilai tersebut lebih kecil dari nilai Lo tabel sebesar 0,140. Maka dapat disimpulkan bahwa kedua kelompok data berdistribusi normal. Selanjutnya, dari hasil uji homogenitas, dapat disimpulkan bahwa kedua kelompok data bersifat homogen karena nilai $F_{\text {hitung }}$ sebesar
1,13 lebih kecil dari nilai $F_{\text {tabel }}$ sebesar 1,69.

Selanjutnya, diperoleh Persamaan $S_{\text {gab }}$ sebesar 15,62. Berikutnya, penulis mendapatkan hasil nilai $t_{\text {hitung }}$ sebesar 1,69 dan $t_{\text {tabel }}$ sebesar 1,667. Dengan demikian, diketahui bahwat $t_{\text {hitung }}>\mathrm{t}_{\text {tabel }} ; 1,69>$ 1,667 yang berarti signifikan.

Berdasarkan analisis tersebut, maka dapat disimpulkan terdapat pengaruh yang positif dan signifikan penggunaan media gambar terhadap keterampilan berbicara bahasa Inggris pada mahasiswa STBA Pertiwi, Cileungsi.

Setelah peneliti menyimpulkan hasil penilitian, maka peneliti dapat menyarankan bahwa penggunaan media pembelajaran yang digunakan seperti media gambar hendaknya ditingkatkan, karena dengan menggunakan media gambar yang lebih sering dan baik dapat mempengaruhi keterampilan berbicara bahasa Inggris.

Adapun untuk memudahkan
mahasiswa dalam menguasai
keterampilan berbicara bahasa
Inggris maka pengajar hendaknya
lebih kreatif dalam memberikan
metode pembelajaran bagi
mahasiswa sehingga dengan metode
yang bervariasi membuat mahasiswa
tidak merasa jenuh untuk belajar
keterampilan berbicara bahasa
Inggris.

Kemudian, komunikasi dua arah antara pengajar dan mahasiswa harus ditingkatkan agar proses belajar mengajar jadi lebih hidup, efektif dan menarik dan akhirnya tujuan belajar mengajar pun lebih mudah tercapai. 


$\begin{array}{lll}\text { Berdasarkan hasil penelitian, } & \text { bahasa Inggris. Peneliti berpendapat } \\ \text { maka peneliti berharap ada } & \text { bahwa dengan adanya penelitian } \\ \text { penelitian-penelitian lain yang } & \text { tersebut, para pembelajar bahasa } \\ \text { membahas lebih banyak lagi tentang } & \text { Inggris sangat terbantu dan dapat } \\ \text { metode, teknik, strategi, media } & \text { mengikuti proses pembelajaran } \\ \text { pembelajaran yang bermanfaat dalam } & \text { dengan baik. }\end{array}$

membantu proses pembelajaran

\section{DAFTAR PUSTAKA}

A.S. Hornby. 2006. Oxford Advanced Learner's Dictionary. Oxford University Press.

Arikunto, Suharsimi. 2013. Prosedur Penelitian Suatu Pendekatan Praktik. Jakarta: Rineka Cipta.

Brown H, Doughlas. 2010. Language Assessment: Principles and Classroom Abilities. New York: Longman.

Celce-Murcia, MsOlshtain, E. 2001. Discourse \& Context in Language Teaching A Guide for Language Teachers. Cambridge University Press

Djamarah, S.B. dan Zain, A. 2010. Strategi Belajar Mengajar. Jakarta: Rineka Cipta.

Mckay, Sandra Lee dan Nancy H. Hornberger. 2009. Sociolinguistics and Language Teaching. London: Cambridge University Press

Richard, Jack, A. dan Renandiya, Willy, A. 2002. Methodology in Language Teaching. Cambridge: Cambridge University Press.

Sadiman, Arief S dkk. 2009. Media Pendidikan Pengertian, Pengembangan dan Pemanfaatannya. Jakarta: PT Raja grafinfo Persada.

Sugiyono. 2013. Metode Penelitian Pendidikan (Pendekatan Kuantitatif, kualitatif, dan $R \& D$ ). Bandung: Alfabeta.

Susilana, Rudi dan Riyana, Cepi. 2007. Media Pembelajaran (Hakikat, Pengembangan, Pemanfaatan dan Penilaian). Bandung: CV. Wacana Prima.

Tarigan, Henry Guntur. 2015. Berbicara Sebagai Suatu Keterampilan Berbahasa. Bandung: Angkasa.

194 | Jurnal Kredo Vol. 2 No. 2 April 2019 